\title{
FROM NEW YORK TO THE WORLD An Interview with Tato Laviera
}

By William Luis

Tato Laviera is a prolific poet. In a relatively short period he has published four books and is finishing a fifth, and this accomplishment makes him one of the more active writers of his generation. Tato first revealed his poetic talents with La Carreta Made a U-Turn, a rewriting of sorts of René Marqués's well-known play La Carreta. His poem "Jesús Papote," from Enclave, confirmed his talents. The poem has already found a place among the celebrated works of Nuyorican writers and is perhaps among the best poems by a Latin American author. "Jesus Papote" is written in the tradition of the long poem, and it captures with precision, depth, and emotion the life and struggles of a people who have been "down" but not "out." "Jesús Papote" is the voice of many Puerto Ricans who have been excluded from realizing the American Dream.

Readers familiar with Tato's poetry recognize that his poems are broad-reaching and respond to a diverse audience as represented by Nuyoricans, Chicanos, Caribbeans, Latin Americans, and Afro-Americans. His poetry is full of the music of bomba and plena, and of rap and preaching. However, it is also socially minded and historical in content. Indeed, his poems are a conglomeration of voices, songs, dialects and cultures producing a unique synthesis which is moving, instructive, and aesthetically appealing.

Tato's books and poems are rich in symbolism and multiple in meaning, in the traditional poetic sense, but also in regards to their use of Spanish, English, and Spanglish words which allude to different linguistic referents. If Enclave refers to a certain musicality, as in the Spanish instrument "la clave," and, at the same time, to a particular surrounding, as in the English enclave, it also addresses a personalized and hidden language code, as in the Spanish "en clave" to which a privileged few have access.

Tato's latest works attempt to broaden his readership and will demand a comparison between his works and those of other Latin American writers. Equally important, Nuyorican writing, in general, and Tato's work, in particular, can be read within the framework of the literature of the post-boom period insofar as it takes advantage of the literary space created by the "boom" writers such as Fuentes, García Márquez, Cabrera Infante, Cortázar, and Vargas Llosa, who have brought Latin American writing to the attention of the world. But the space that was created by these and other writers has allowed for the development and publication of a marginal and lesser known yet nevertheless important type of literature which includes women and Blacks and also Nuyorican and Chicano writers. In addition, the literature of the latter two, which is written in the United States, embraces some of the characteristics of the literature of transmigration and exile. There is tension between the country of origin and the adopted one which the writer accepts on an intellectual level but not an emotional one. Within a different context, the writing is also undeniably North American as it recalls the works written by Afro-American authors in exposing the lives of those who have become a part of the expansion of North American literature and culture. 
In this interview Tato talks about his life and works, about his social and political responsibilities, and about the development of his poetic voice, a voice that appeals to Nuyoricans and Latinos in the United States, but also to a broader audience. To some degree, Tato, the poet, is the "esquina dude" of AmeRícan, someone attempting to expose a certain reality to survive in the (publishing) world. Tato has published La Carreta Made a U-Turn (1979), Enclave (1981), AmeRícan (1985) and Mainstream Ethics (1988), and is in the process of completing his latest book of poems, Continental. The following interview was conducted in December of 1989, on the campus of S.U.N.Y. at Binghamton where Tato was an invited guest.

LUIS: Tato, let's start with your childhood in Puerto Rico and your coming to the United States.

LAVIERA: I was born in Santurce, Puerto Rico, in 1951. My first thoughts are of sounds, music, and words associated with a place I used to go to every Sunday called Piñones. I was born during the era of Rafael Cortijo y su combo and Ismael Rivera who used to work for my father. I used to write jingles, especially around Christmas. I went to school when I was 2 years old. My mother put me in a private school called Jesusa. So when I went to public school, I got skipped from the first to the third grade. After public school I went to Padre Berrio's where I completed the 3rd grade. In the 4th grade, I went to Cantera, Padre Celestiano in San Juan Bosco, a very well-known school in Puerto Rico. I was an altar boy from the time I was six, a very good altar boy, and then my family left for New York City in 1960.

LUIS: And your coming to the United States was part of the post-World War II Puerto Rican migration process.

LAVIERA: Yes, my coming to the United States was precipitated by my sister being eight months pregnant and my father not knowing about it. My mother wanted my sister to give birth in New York City, away from my father's anger. And when I left my house, I didn't know I was coming to the United States. I was on the plane and I had vivid images which I included in the poem called "Negrito," in AmeRican. Once on the plane, I thought the U.S. was all white, and I was scared I'd be the only Black person going there. I was totally terrified when the plane was landing. And in my poem called "Negrito," I say:

El negrito
vino a Nueva York
vio milagros
en sus ojos
su tía le pidió
un abrazo y le dijo,
"no te juntes con
los prietos, negrito."


My uncle used to work in the airport, so my family came to meet me by the plane. When I came down from the plane, I saw these Black people and I felt good. But my tía politica grabbed my hand and said: "No te juntes con los prietos, negrito." It was the first thing that I was told and here I'm thinking that there weren't going to be any Black people around. I responded: "Pero Titi." and she said: "No te juntes con los moyetos, negrito." "Pero Titi." "Si los cocolos te molestan, corre y si te agarran, baila." That was my first welcome to New York. Nueva York me saludó y me dijo "confusión." My family proceeded to take me to the Williamsburgh area, which is all Black, and so my whole image changed; I didn't know what was going on. First I thought everyone was all white and then my tía me dice eso and proceeded to take me to an all Black area. I was totally shocked. Plus, I didn't know I was coming here and after six years my life was totally transformed.

LUIS: We can trace your poetic talents to when you were a child and wrote jingles. But when did you become aware of your poem-writing abilities?

LAVIERA: The first poem I wrote was "Even Then He Knew," of La Carreta Made a UTurn. An incredible thing happened. I was sick and there was a building they were fixing across the street from where I was living, on 7th Street. I was very ill that day. And this kid, I called him Papote, was sitting on the steps of the building at 1 o'clock when I came out; he was sitting there at $3 o^{\prime}$ clock when I came out again. I looked out the window at 5 o'clock and he was there; él estaba descalzo. I looked at him and then me cogió pena. I said: "Mira, espera alli." I went to get him a sandwich and a soda. I came down the stairs and when I went out he was gone. He was there for five hours. So I went and sat on the stairs and wrote my poem about that kid. And this great Puerto Rican painter came by. I read him the poem and inspired him so much that he came back with a painting three hours later. It was right there that "papote sat on the stoops ... and he decided to go no where." I showed my friend the poem and three hours later, por el amor de Dios, this guy, Sánchez was his name, came back and showed me a painting. It was destiny. I didn't want to meet him again because of my good luck. At 11:00 p.m. I had a painting and a poem about that kid. That was the calling. It was a concrete calling and there it emerged. This happened in July, 1966.

LUIS: You write theatre and poetry; how do you interpret these two different literary genres? What do poetry and theatre do for you?

LAVIERA: Basically, I discovered early that there is so much wealth of characters and attitudes in poetry. There are so many different styles of talk that characters inspire me to write. I always tell people that the two most developed organs are the mouth and the ears. I've had eight plays produced and five books published in the last ten years. I tend to write characters and situations. The characters of the poems spiritually push me to create the drama of the theatre. The poem gives me the characters and the drama follows them. Keep in mind that I had a very good schooling with The Teatro Cuatro. I was the head of the Shakespeare Festival Latino. I worked with the Festival for five years. Since I was so secure with poetry, the theatre became an ex- 
perimentation with actors. The openness of the theatre allowed actors to go and get experience from the street, using our own intelligence and research. I was able to write from a collective perspective. So theatre was easy for me. I like the whole idea of working with people to create movements. Also, I had an excellent man who cared for my body of work: Woody King, Jr., under whom I was a director of Hispanic Theatre for five years. Through him, in my workshops, I had three plays produced with my students. The plays had a six week run. I had a Black American person who committed himself to the body of work of a Puerto Rican writer.

LUIS: I gather that when you came to the United States, two things were helpful to you. One was your knowledge of Latin, which is associated with your religious training, and the second was your command of history. You use historical facts in your poems. For example, in your poem "Lady Liberty," you depend on historical information to create images. But I want to talk to you about how you incorporate your religious beliefs into your poetry, in particular in "Jesús Papote," your most important poem to date. How did your religious training help you in writing that poem?

LAVIERA: I think your questions all tie in together. There is the occasional poet in me, and I think he has to do with the Puerto Rican feeling of Spiritualism. You see an object, and it represents thought, spirituality, physical presence, and history. Through Spiritualism, the person in front of me is always present in history. Through vibrations, I can define that person at any given moment. What has been called the "real maravilloso," the clash of African religions, Caribbean rhythmic patterns, and the footing of bomba and plena, and the religious framework of Catholicism, have allowed me to look into the soul of characters.

LUIS: What is the most important component of your poems?

LAVIERA: I live for the title. I am a title poet. The words of the title are the ultimate essence, and the background of my writing is to bring the title to its most total development. So, the religious allows me to concentrate on the titles. The titles are occasioned and have all kinds of innate, internal, and spiritual bodies. They have some kind of goodness or badness, they have a total experience to them. The religious and the discipline of dealing with the title bring out the social and the political. The religious gives me the discipline to get into the background of the poem and the essence of the title.

LUIS: "Jesús Papote" is a religious poem in which you describe an anti-Christ figure. It is interesting to note how you rely on the Christian tradition in which Easter represents death but also resurrection, and Christmas the birth of Christ. In your poem, conception takes place in Easter and birth, the birth of a certain death, is associated with the birth of Christ.

LAVIERA: Yes, "Jesús Papote" is very structured. First of all, it's a nine month cycle; there are no commas, so its all conceived in the breath of the woman's push to give 
birth; it happens on Christmas Eve, which is supposed to be the most serene night in the Christian calendar. Our time is defined by Christ's birth. We live in the image of Christ's death and in Christian time. To take the moment of his birth, to put the trauma of death inside the month of his birth is the very structure I use to tell history. I think the Catholic in me provoked the universality in the poem. Each piece or part had to do with looking into a character and understanding its good and bad points. There is a lot of religious symbolism in it. The fact is that I end en la misa del qallo, at 12:00, Midnight Mass. The Jesús Papote legacy was to be in church with God; it was almost like saying Christ has to come many more times. The old Christ has to incarnate himself, the new Christ has to give us a new image of what the world is about, because the Bible, as much as we try to interpret it, does not give us the moment in time that we live under.

LUIS: In your poem, Christ is not a sacred figure. He is sacred in the sense that he follows the religious interpretation but you take the Christ symbol and turn it upside down. The Virgin Mary, who represents a sacred and pure (virginal) mother, in your poem has become a junky. She isn't impregnated by the Holy Spirit but by every Tom, Dick, and Harry, and no one knows who is the real father of her son. She is a junky, and she and the Christ figure struggle together to help her kick the heroine addiction. Jesús Papote is going to be born into a world of death and destruction.

LAVIERA: The difference is that Christ resurrected from the dead. If he had not resurrected, time wouldn't be defined by his nature. Christ was someone who was crucified and killed and resurrected. My Jesús Papote had to be crucified by society.

LUIS: Your Jesús Papote is crucified before he is born; his crucifixion begins in the womb.

LAVIERA: Yes, in the womb, so that in his birth, at least when he comes out, the voice would be heard. I was looking for a voice and he gave me a voice that I wish my people would listen to for once. In order for him to have qualified to be the voice, he had to go through an enormous struggle, so when he said that word, "Bendición," it was pure. His resurrection was coming into the world. He came as a hero who could at least speak to my people on something which I didn't find in anybody else. My Puerto Rican people do not have a hero-I couldn't find one. So, having crucified him in the womb and at the point of his birth (or at the moment of his death), my people would say let's listen to this character. I was looking for an epic character who my nation would hear, because my nation doesn't listen to characters. I think I succeeded in making him an epic figure, and that was my goal. He had to go through all those things so that everyone in my community could just lean back and hear this guy say "Bendición" and live. I guess his womb was his crucifixion and his birth was his resurrection.

LUIS: Language and voice are very important in your poems and also in the poetry of Nuyorican writers. The presentation of the poem is as important as the writing of 
the poem and, in that sense, I notice the influence of not only the poetic genre, but also of Afro-American culture as represented, for example, by a minister or a preacher. To some degree, you are a preacher, or even a soap box politician on the corner talking to the people. So the recitation of the poem is extremely important and, unlike other poems written in other countries, the poetic style of Nuyorican poetry is conversational and must be spoken. In effect, the poet is talking to the people.

LAVIERA: Absolutely. The spiritual force guides my poetic persona. When you call yourself a poet, you define yourself as someone who doesn't appear in the growth of the GNP of U.S. society. Before, the poets of God were heralded, but now we are unheralded. But if you give me a moment, I will read my poetry. Politically, I have gotten to the point that with my four or five books, I can read an hour in Spanish and an hour in Black. Being Puerto Rican gives me the totality of having a universal mission to talk to different groups at different times. And the fact that I do it in Spanish and English allows me to talk to the entire continent. Listen to my images and you will see that I'm a continental person. Spanish is a major language spoken in the continent; English is a dominant language of the society in which I live. For the countries of the New World, my two guns are the major languages, Spanish and English. Being an oral poet binds me to other oral poets and historically to all the great poets and poems of the world. Oral poetry is an art that is still alive. It is a tradition of Europeans and Africans who used to tell stories. By talking my poems, it binds me spiritually and morally not only to the presence of many nations but to a poetic chain of historical importance. Being a declamador binds me historically; being a Rican, it binds me to my people in their clash with society. It gives me the "bilinguality" of being able to absorb the contradictions of different forms, the Blackness with the "colloquialness" of my people and the formality of Spanish and the tensions that arise in urban society. I'm a Nuyorican but I never call myself a Nuyorican. People call me a Nuyorican and I accept it totally. Some people don't want to accept new terminologies. I believe we have cinco gorras; we wear the Hispano hat which answers to Latin America; we wear the Caribbean hat which binds us to Blackness; we wear the Nuyorican hat which binds us to the present society; we wear a Puerto Rican hat which binds us to our country, Puerto Rico; and we wear the Latino one which binds us to this nation. We wear all those hats. In the meantime, it is my responsibility, as effectively as I can, to let the voices of my people, at any moment, integrate into me and I just give it back to them the way they give it to me. Somebody asked me who's in your poem? There are a thousand people in every syllable. And I definitely believe the mirror imagery of giving a voice back to the people, because the people give me the voice, they give me the characters, they give me the moment and the reason for being. I'm lucky that I am able to give it back to them. So my objective is to give it right back to them. I know a couple of things. One, there are no Puerto Ricans anymore who don't understand English. I don't care who they are - they may not want to speak it but they understand it. Two, there is an accepted cordiality that when you do speak Spanglish, it's funny. It's funny, pleasant, and its how people talk. Three, there is a very warm bonding between parents of the 2 nd generation and the grandchildren of the 4th generation. And more than anyone else, we have resolved that problem. Que el nieto sea 
el roquero más grande del mundo y que se vista con el beep bop. Lo que importa es si es buena gente. There is no problem at all with that. We have a great ability for allowing integration, experimentation, and keeping a certain basic to ourselves without going through too many changes. In that way, the Puerto Rican persona is, I consider, an advanced person in society, in the humanistic category, in the social category, and in the political category, in terms of dealing with people, and in the spiritual category, in terms of accepting people. The Puerto Rican persona is very broad and he allows experimentation without a lot of psychological hang-ups. He is very broad natured and I think here's where our artistic totality lies; artistically we are very broad.

LUIS: Let's continue with the concept of Puerto Ricanness and the ideas you express about the two languages, because Spanish and English are important in your poetry. To what degree do you use Spanish in your poems as a way of being accepted by a Puerto Rican audience and writers on the Island.

LAVIERA: There is nothing creative about my poems. Everything is structured so that nadie me joda. I have published 198 poems: $60 \%$ of the poems are totally in English, $20 \%$ of them are totally in Spanglish, and the remaining 20\% I write in total Spanish. I knew politically I had to do that. I like the Spanish language, but I have to look for a balance. I'm not saying that I'm the best writer, but politically, I have not been criticized. If I say I cover my angles, you know why, porque la comunidad puertorriqueña es la comunidad más bochinchosa en el seno del mundo. If I don't please all of them, me jodo. I'm in trouble because they'll find some fault porque tú no hiciste esto y porque tú no hiciste lo otro. So politically I have to write Spanish and English to cover all the grounds of my people. No quiero pleito con la gente mía.

LUIS: The balance must be working because your books have become popular. Yet you seem to borrow from works written and published on the Island.

LAVIERA: I hold a couple of records. I like that, you know. In La Carreta Made a UTurn I bastardized the most sacred Puerto Rican book, the best play, René Marqués's La carreta. First of all, I used his structure. I'm a Marquesian and Marqués defines my poetic structure-he always has. Yo también tenqo tres secciones. He began in la montaña and continues in San Juan, and then goes to the metropolis. I began in la metrópolis and instead of ending in the Island, I make a U-turn and go to el arrabal, into the streets of Loisaida. If Doña Gabriela went back to Puerto Rico, in La Carreta Made a U-Turn, my characters go back to New York. My book becomes an extension of his; it's a fourth act to his play. In my first section, which is written mainly in English, I include references to Muñoz Marín. In the second, I include all women. I believe that politically I have to write about women. Of all the poems I have written, forty-one of them have characters which are exclusively women. Yo estoy solito alla afuera with that. And good characters, characters of women that I respect and that women use. I had to make sure that I have women that speak in my poetry by themselves and have a very feminine structure. There is also a Black structure. La Carreta Made a U-Turn was to proceed deeper into New York, but I ended it in Spanish because politically, if I didn't end it 
in Spanish, being in the U.S., then I would have been in trouble. So how could $\mathrm{La}$ Carreta make a U-turn and proceed into the U.S. and not end in Spanish? To create a book of poetry, to me, is a political jumble. It's not how come I wrote the poems. They have to be first of all political, because I have to sell the books. Who wants to print poems? I mean, for me to have printed four books in ten years, it is a remarkable achievement. The poet in me is at the minimalist edge of society. In order to contain that minimalist in me, I have had to become sharp in many respects. I have not been criticized linguistically; and politically I have never misspoken. Based on the four books, I have remained politically correct. And in my latest book, Mainstream Ethics, you see the same thing. I was calling myself "mainstream" and that is a very dangerous title. But I began with "Lady Liberty" which is in English - this book goes from English, to Spanglish, to Spanish, and I end it with "Conciencia," which is my Latin Americanization:
te hablo porque puedo hablar
tengo la confianza que entiendes
mi genocidio mi pesadilla
mi esclavitud mis cadenas invisibles
mis libertades falsas
te digo que nuestra gente duerme.

In other words, I end with the voice of Latin America and not the voice of my people from El Barrio hispano. The voice of Latin America had to emerge in the end; that's Mainstream. It's in Spanish and in English and both worlds live in my Enclave.

LUIS: So you are mainly interested in reproducing the language of the people.

LAVIERA: Politically speaking, I would never write a book of poems in one language or the other; it doesn't work with the balance of the way my people as a whole refer to themselves. I always say I'm a Puerto Rican poet, I want to be able to recite where my people are, which is not only in Spanish or English but both. That's my criteria for being a universal poet. I like the way the Europeans define me. I don't like the way the Puerto Ricans define me. They try to place me in certain structures. I'm never monolingual because I write in Spanish and English and in Spanglish. The Europeans say that I write two colloquial languages that are European in the context of the New World. I accept that. Yo me quedo con lo que los europeos dicen. Y lo que los puertorriqueños me dicen está con mucha chuchería. The Europeans study and write about my work. They have earned the dignity of my attention.

LUIS: Before we move on, I want to go back to your writing in Spanish and in English, which symbolizes the tension that exists between the Puerto Ricans in the U.S. and the Puerto Ricans on the Island, a theme present in Pedro Juan Soto's Ardiente paciencia, fría estación. As you may recall, his novel refers to Nuyoricans who go back home to Puerto Rico but are not totally accepted. This idea seems to be represented to some degree in the writings of Puerto Rican authors born in the States. Writers in Puerto 
Rico are accepted by Puerto Ricans in the U.S., but it is somewhat problematic when you consider how it works or does not work with Nuyorican writers in Puerto Rico. You, Miguel Algarín, Miguel Piñero, Nicolasa Mohr and others have talked about trying to forget about being accepted by the people on the Island, because they don't seem to be as forthcoming as they should be. Do you want to elaborate more on the tension between mainland writers and island writers?

LAVIERA: I have no problems; I don't pay any attention to the tension. As far as I'm concerned, I don't experience any tension in Puerto Rico. In that respect, Puerto Rican writers from Puerto Rico cannot come to the U.S. and be Puerto Ricans. The spectrum of the U.S., as a nation, includes Chicanos, Latinos, Hispanos, Cubans, Mexicans ... They cannot come into communities and be totally successful. They really can't; they can't come and talk to the masses, to twenty million Latinos of this nation. I can do that. I can go into any barrio, whether it be Chicano or Cuban or Puerto Rican. The broadness of my experience as a Puerto Rican here has allowed my work to be successful. I could do an hour's work or two hour recital to these people and be totally inclusive about their attitudes and ideas and be totally accepted; that's what I have tried to do in the U.S., to be accepted by all the communities as a poet and be loved. The Puerto Rican consciousness has developed and I give that credit to my people; they've really branched out in a humanistic way which allows us to communicate. If I go to Puerto Rico, I would probably stay Negroid because yo soy un negro de Puerto Rico. I happen to believe that I, with my Negroid poetry, I can live in Puerto Rico, en cualquier esquina, you know. You have to have your protections. In cualquier sitio I can say:

retumba el pasado presente prosa poesía retumba el calor sudor vaivenes de cuero salpicando mares olor tambor prieto quemao orgullos cadereando acentos al español conspiración engransando ritmos pleneros a la lengua española pa ponerle sabor.

pero que tetumba en la tumba resbalando pico pico tun tun de pasa áfrica se pierde en puerto rico tirando pasos richos a los santos carcando al uno dos en tres por cuatro que alientan los versos exaltan los salmos despierta la clave chupando las cañas pracutú-piriquín-prucú-tembandeando el secreto máximo: que luis palés matos tambie'n era grifo africano guillao de castellano.

$Y$ por allí palante. I have my spiritual protections going to Puerto Rico and tú puedes decir lo que tú quieras. Pero si tú te paras conmigo para recitar y me paro en cualquier lado, verás que quedo bien con mi pueblo y los portorros sin duda. My answer is that it doesn't 
apply to me, and I also know for a fact that it doesn't apply to people like Pedro Pietri. If Pedro goes to Puerto Rico, en cualquier nivel, intelectual y espiritualmente, y él no recita en español, people love him. And one of the things that's good to know is that at this point historically the English and the Spanish are not the question. The attitude of the English is what is important. Fortunately and unfortunately, my nation is bilingual. The people are into the English and into the Spanish, and if you do it right, no matter what language, it's fine. My second thesis is that Spanish is not an issue in this country; Spanish is the most grounded language in this country. No hay problema con el español. For every five Nuyoricans who are born speaking "Spanglish," there're ten Dominicans that come and bring the Spanish over; and there're twenty-five salvadoreños that bring it over. Spanish is constantly being reinforced so there's no danger of Spanish being lost in this country. Eso no es un problema. El español categorically is the most developed literary language in the continent, in the hemisphere, probably in the world. The reality of Spanish is not that it is being tumbao, just because of certain migrational experiences and all of that. Yo entiendo que the only good Spanish is the atom bomb y eso es una cosa pero correcta. What we need is the interaction to understand the experiences of people, to understand the experience of migration. Now being a Nuyorican, one of the things that I've noticed is that the world is in a bilingual tension: the Africans in Europe, the Turkish in Germany. There are movements from mother country to urban centers in conquering countries and it is not isolated to Puerto Rico. As Nuyoricans, we have captured the political and linguistic changes. People are looking for a Spanish or an English or a German point of view. But if you think about it, Europe tends to be multilingual. America isolates itself in the English only and it wants to control biocenosis. You can't do that-it's a stupid move. It's exercising bigotry. But the broad world isn't looking at it that way; the linguistic tension exists everywhere in the world and the Nuyorican element of it, prestigiously, has grown in many ways. I'm not saying that's the only school of Puerto Rican writing, I'm not saying that I know, but, I'm saying that there's nothing Puerto Rico can do about bilingualism. It's a fact of life and a fact of world movement. That's the way I see it.

LUIS: Let's continue with the idea of branching out. As you begin to branch out, to reach a broader audience, as defined by a Latin American audience, and also a broader audience, as defined by a mainstream North American audience, will your voice and images change as you begin to move in wider circles?

LAVIERA: No, but what I need to do is to keep abreast of the movement. Right now, for instance, I'm testing myself with a Latin American audience, testing to know what I have to offer. Let's look at the reality of writing my new book, Continental. The three sections in Continental speak to the necessity of what's going on in the world and what's going on in my life at this particular moment. I have already selected the titles for the sections. One section is called "Indigenous," and the titles are Preservation, Inca, Maya, Borinquen, Arawak, Sioux, Navaho, Afro-America, and Drum. In the section called "Patrias," the titles will be Cuba, Sandinean, Martí, Campesino, Marxista, Negrista, Canción, Buyeralo, Guitarra, Brazil, Ayende, Tumpac Amaru, Tang, Panama ... In the Caribbean section, the elements will be Blackness, Islandhood, 
Potencias, Blue, Green, Yellow, Red, Blackness, White, Orange, Brown, Purple, Coca. The elements in Indigenous are the drum; in Blackness, the conga; in Patria, la guitarra. My reality right now tells me that I have to expand here; what this says is that this is a whole Latin Americanization. I'm leaning in that direction. It's not going to be all in English or Spanish, because some of these terms the American people want to know and I want them to know them. But it's obvious in Continental, in branching out, that there's a whole Latin Americanization in me, and there's a whole Indigenous expansion in me; and there's a whole Caribbean expansion in me. Those are three areas I think are important that I need to cover right now. That to me is not politics but is giving importance to the world and to Latin America. I feel I have a responsibility to assist in defining it, to define it for myself, and to work with it. It's obvious that Latin Americanization of the Nuyoriqueño is a very important aspect of my new work.

LUIS: And what about the North American audience?

LAVIERA: The North American audience is also going to be represented in my work; it will be in the area of lyrics. "Dancing in the heat of $m y$ salsa, dancing of my choice, dancing Casa Blanca con sus ochenta." It will be taking lyrics and adapting them to American music. Taking poems and adapting them to music. Through lyric and music developments I am going to try to reach America.

LUIS: And you're also writing in English.

LAVIERA: Yes, I'm writing in English and the pieces are there. I feel I wanted to be able to say that I've done it already; I could do intellectual America pretty well. It may not be in the best written form, but I want to have an hour of poetry for everybody and be successful. People would say: "Hey! That's pretty good!" I want to be one of the boys, a respected boy. I think I've achieved that. Now I just need to expand the English. I think the Caribbean section is going to have the themes with the colors; it's going to be not only very musical, but is going to have seasons. One good thing about the American mind is that it is respectful of seasons. It is a nice American value. I'm going to try to use these seasons to get closer to a theme that I feel in America that I like.

LUIS: You talked about Pedro Pietri and it's clear that Pedro's influence is present in your works. Which other writers have influenced you?

LAVIERA: I don't know. I have a hard time answering that question. I'd like people to tell me.

LUIS: Do you write from no tradition? Is it possible to say that Nuyorican writing, which is born out of specific socio-historic circumstances, has no tradition?

LAVIERA: I have personal definitions for how I'm stimulated by others. I call them "schools." Some of our poets use very muscular verbs. Others are spiritual, satiric, 
and comic. Our poets have that crude raw power of politics at the elementary level and some have the Afro-American rooted lyrics, the rap quality. I have a lot of respect for poets. If you give me a poem I can teach it to you. I teach the poem, not the poet. You give me the poem of a poet and I'll break it down for you. I will do an experiment so you really get to learn it and be enthusiastic, but my contribution in that area is to be able to define the poem of the poet rather than the poet.

LUIS: In your branching out you are becoming a universal poet.

LAVIERA: I want to reaffirm that, first of all, I'm becoming a poet, not a Puerto Rican poet or a Nuyorican poet. The way I have structured these 198 pieces of solid sweat have qualified me to be a poet. As a Puerto Rican, tengo cinco gorras. There is no way that I could reach my Puerto Rican population totally in Spanish, so I don't consider Spanish as being the totality of being Puerto Rican. English is another reality. I love the language and I need to use it. Another reality is the colloquial, everyday, linguistic patterns of code switching which I find brilliantly exciting and which many have accepted as a normal way of life.

LUIS: I've noticed that when writers begin to branch out, their styles seem to change. For example, let's look at the generation of 1940 Puerto Rican short story writers who wrote about migration. Those who are still writing today are making the working class Puerto Rican characters speak standard, flawless Spanish, which is an attempt, in my opinion, to reach a broader Latin American audience. In addition, they are also publishing outside of Puerto Rico, which is part of branching out. In other words, the voice that made them popular, which allowed them to reach a particular audience, has changed. I was wondering if some of those changes are going to be seen in your work.

LAVIERA: I don't think so because of what I have called my disciplined habit of finding a voice and it telling me, whether it is in English or Spanish, tienes que ser auténtico, you know. I like authenticity. That's the way Latin America is going to branch out into me, the way I'm going to meet it and the way Latin America is going to meet me. 